UDC 94(5)

DOI https://doi.org/10.24919/2308-4863/44-1-4

\author{
Artem KOLOS, \\ orcid.org/0000-0002-9129-7166 \\ Graduate student at the School of History and Culture \\ Shaanxi Normal University \\ (Xi'an,China)artemkolos@gmail.com
}

\title{
PRECONDITION FOR EMERGENCE OF TAIWANESE IDENTITY, ITS RELATION TO CHINA AND CRITIQUE OF MODERNIST APPROACH
}

This article focuses on analysing the unique preconditions that lead to the emergence of unique Taiwanese identity. At the same time, author identifies some flaws of the modernist approach towards research of nationalism. While not denying the importance of the modernist school, the author points out that the premodern era is not a tabula rasa, and there should be certain pre-conditions that allow modern nations to be formed. This paper argues that one such condition is a sense of commonality, which is developed within a group of people living on the same territory and under the influence of the same common factors. The Taiwan example shows that people tend to develop a sense of commonality based on their shared experience of interacting with the environment. Moreover, at the same time, the author is denying primordialist argument. This paper states that a sense of commonality is not permanent and is constantly changing - even though the majority of Taiwan's population are immigrants from mainland China, they feel less and less commonality with the Chinese population. As long as they live on different soil, they have different experiences in terms of interacting with the environment, and they eventually begin to evolve differently as well. The problem of self-identification of certain populations should be regarded through all the continuity of shared experiences that they have obtained. The main factors regarded in this paper are ethnic composition that changes drastically due to inter marriages, religious practices that begin to change their characteristics under new environments, and languages that begin to sound differently by absorbing more words from other languages. As the result, people who share the same ancestry will enter into the so-called modern era under very different conditions, and therefore will end up adopting almost diametrically opposite political systems. This paper sets out to prove that the democratic system adopted in Taiwan is a direct reflection of the collective experiences of the people that inhabit this island.

Key words: taiwan, nation, ethnicity, religion, language.

Артем КОЛОС, orcid.org/0000-0002-9129-7166 магістр факультету історї та культури Педагогічного університету Шеньсі (Сіань, Kumaŭ) artemkolos@gmail.com

\section{ПЕРЕДУМОВА ВИНИКНЕННЯ ТАЙВАНСЬКОЇ ІДЕНТИЧНОСТІ, Iї̈ ЗВ’ЯЗОК ІЗ КИТАЕМ І КРИТИКА МОДЕРНІСТСЬКОГО ПІДХОДУ}

У статті акиентується увага на аналізі особливих передумов, які призвели до появи унікальної тайванської ідентичності. Паралельно автор виділяє деякі недоліки модерністського підходу до дослідження націоналізму. Не заперечуючи важливості модерністської школи, автор зазначає, щуо епоха премодерну не є tabula rasa, тому мають бути виконані певні передумови, щзо дадуть змогу сучасним націям сформуватися. Стверджується, щзо однією з таких умов є почуття спільності, яке розвивається в групі людей, які прожсвають на одній території та перебувають під впливом одних і тих самих спільних факторів. Приклад Тайваню показує, щчо люди схильні розвивати почуття спільності на основі спільного досвіду взаємодії з навколишнім середовищем. Більще того, автор заперечує примордіальний аргумент і наполягає на тому, щь відчуття спільності не є статичним і постійно змінюється. Незважсаючи на те щзо більшість населення Тайваню є іммігрантами з материкового Китаю, вони чим далі, тим менше відчувають свій зв'язок із населенням материкового Китаю. У зв'язку з тим щзо люди живуть на різних територіях, иче призводить до отримання різного життєвого досвіду щзодо взаємодії з навколишнім середовищем, тому і їхній розвиток відбувається по-різному. Проблему самоідентифікації певних груп населення варто розглядати через призму безперервності спільного досвіду, який вони отримали. Основними факторами, щуо розглядаються в статті, є етнічний склад, який різко змінюється через міжетнічні шлюби, релігійні практики, щзо починають змінювати свої характеристики в новому середовищі, і мова, яка починає звучати по-іншому, поглинаючи більше слів і термінів з інших мов. У результаті люди, які мають спільне походження, увійдуть у так звану сучасну епоху модерну за зовсім іниих умов, а отже, у кінщевому підсумку приймуть майюе діаметрально протилежні політичні системи. Стаття має на меті довести, щзо демократична система, прийнята на Тайвані, є прямим відображенням колективного досвіду людей, які населяють цзей острів.

Ключові слова: Тайвань, нація, етнічна належність, релігія, мова. 
Introduction. The actuality of the subject. It appears that the notion of Taiwan being an Imagined community naturally comes to mind of those who truly believes that a nation is the product of social construct. Taking as granted the Modernist theories of Benedict Anderson, Ernest Gellner and Eric Hobsbawm, it seems that if the population of Taiwan shares common ancestry with the population of China, then the reason why Taiwanese want to be independent is a pure social construct. According to Benedict Anderson, a nation is "an imagined political community" that exists as a result of so called "print capitalism". The hypothesis of "print capitalism" implies that the idea of common identity within the nation is emerged from the use of the printing press, spread under the capitalist market system (Anderson, 1991: 6-7). Differences in the content of newspapers create a barrier in which people of the same ancestry are separated due to the difference of the information they absorb. Therefore, it easily can be deducted that Taiwanese people crave for independence from China because of their democratic system and freedom of speech - things that are non-existent in Chinese media. As a result, values of these two peoples are evolving in different directions and now they do not have that sense of commonality that they have with people who consume same information that they do.

Scientific novelty of research. It seems that the modernist theory of the emergence of nationalism is capable of explaining only the last stage of its formation. Author by no means is going to deny the aforementioned concepts used by modernists, because it is true that the last step of nation formation hardly relies on achievements of industrial revolution. However, it is fair to assume that sense of commonality within certain communities existed well before the modern era, when products of industrial revolution made it possible to extensively use the printing machine. It is fair to say that so-called nationalism is the product of thousand years of evolution and should be researched by analysing changes that certain community undergo through the span of many centuries. It is also important to note that the reference to the Primordial tradition also must be dropped. Since the majority of Taiwan's population are immigrants and live away from place of immigration, sacred connection between people and land of origin is not the case here. People have a connection to the land and the environment in which they and their ancestors live, but this connection is not permanent and definitely not attached to one same location. In order to really understand how certain communities come to the realization of themselves as a nation, first of all we need to understand how those pre-existing ethnic communities evolved through the ages in all its continuity. Another claim of Benedict Anderson that is repeatedly brought up in "Imagined communities" is that modern nations are not coming from tradition and there are modernistic in nature and based on achievements of industrial society. This concept is very important when we compare The People's Republic of China and Taiwan, because the desire of Taiwanese people to be independent is based on fact that they will not be able to preserve their traditional way of life developed through centuries by being the part of huge industrial machine like PRC that eagerly gives up many traditional institutions and freedoms in order to achieve "Progress".

Purpose and tasks of the research. In this paper Author will try to prove that the democracy, republican system and freedom of speech that exist in Taiwan are not the roots of its unique identity in opposition to China, but are the tools to preserve the freedom and traditional way of life of its population as determined by its experiences of living under specific environment which includes geography, climate, inter-ethnic relationships, language and religion.

Presentation of the main material. In order to begin our analysis of the emergence of the unique Taiwanese identity, we should start with a short trivia about the ethnic composition of the population of Taiwan. The basis for the emergence of a unique Taiwanese identity relies on a high degree of diversity within population of Taiwan that consists both of the immigrant population and the indigenous tribes. What makes this situation even more unique is how this Island managed to absorb population from neighbouring regions. Over the period of more than 400 years, The Island of Taiwan was constantly experiencing an influx of immigrants from Mainland China. What is particularly interesting is that most of these immigrants at some point of time started to identify themselves as Taiwanese. Let's take a look at the common categorization of ethnic groups inhabiting Taiwan.

The population of Taiwan is usually divided into big four ethnic groups (四大族群 sidaqunzu) - the Hoklo, Hakka, Mainlanders, and aboriginal peoples. $73 \%$ of Taiwanese population categorized as Hoklo, $12 \%$ as Hakka, $13 \%$ as Mainlanders and $2 \%$ as Taiwanese indigenous aborigines (Wu, 2021: 150-164). However, this categorization is not based on actual biological differences between people and exists merely in the realm of politics. Even though this categorization doesn't even remotely represent ethnic diversity of the island, it does represent the timing when certain population immigrated to Taiwan. The brightest example is the group titled Mainlanders, which 
literally means people who immigrated from China after KMT collapse at the Mainland. These people largely immigrated to Taiwan after 1949. Many of these people ethnically are Hakka, Hoklo or any other minority from the Mainland China. Mainlanders as an ethnic group do not share the same ancestry. There are significant differences in language and culture within this group, but in the realm of Taiwanese political life they are referred not by their ethnicity, but by the time when they arrived to the island. Within the populations of indigenous people of Taiwan there is no common ancestry either - they, just as mainlanders, are different ethnically, culturally and linguistically. As we can see, ethnic categorization in Taiwan has at least two dimensions - origin of immigration and time. This is of great importance, because, as we will see later, a certain group of people, even if they have a common origin and in terms of biology and genetics, and belong to the same phenotype, will develop differently under the influence of different environments. Eventually, it means that the Hoklo people from Fujian province who immigrated to Taiwan during $17^{\text {th }}$ century have very little in common with the Hoklo that immigrated from Fujian in 1949, even if they have common heritage.

Fujian has been a major source of immigrants to Southeast Asia for centuries. The peculiarities of the mountainous landscape of this territory made internal transportation so expensive and difficult that all the main trade routes to other parts of China passed along the sea coast. Thus, the Hoklo people gained fame as sailors and merchants. The seaports of this region have been functioning for over a millennium since the times of the Minyue kingdom. The Minyue kingdom itself was inhabited by Baiyue people, who were non-Chinese. This kingdom eventually was annexed by the western Han in $111 \mathrm{BC}$ and the Baiyue people were assimilated by the Han people (Carson, 2016: 23). Despite the assimilation, most of people, not only from Taiwan but also from Southern China, have slightly different DNA from northern Chinese (Zheng, 2015: 517-527).

Usually the idea of independence arises from the inability or unwillingness to change your traditions, customs, and economic activities due to the whim of a ruler who is thousand kilometres away. And here we meet the difficult relations between the people of Hoklo and the Chinese government. From the end of the 14th century until the first Opium War and the Nanjing Treaties in 1842, the Chinese government, represented by the Ming Dynasty and then the Qing Dynasty that overthrew it, were with relative success imposing bans on Maritime trade. Even when foreign trade was not categorically prohibited most of the traders who travel overseas were not regarded as law-abiding citizens. During the 17th century, Ming loyalists still were real treat for newly established Qing dynasty. Taiwan was controlled first by the Dutch colonialists and then by the Ming supporter Zheng Chenggong, who expelled the Dutch in 1661. Thus, Taiwan was considered as a security threat by the Qing, and therefore they imposed devastating ban on sea trade. Manchus, who ruled the China under the banner of Qing dynasty, knew very little about sea trade and the Hoklo people in general. The imperial decree stated that any official who allowed the ships to come to the port should be severely punished. In 1661, the entire south-eastern coast was depopulated, the inhabitants forcibly moved inland in order to starve Zheng Chenggong's people and inhabitants of Taiwan (Shi, 1995: 4-23). Official policy of the state were against geographical reality of this area as well as the set of beliefs and economical activities based on it. People who are sailing the ocean for thousands of years were forbidden to engage in a craft that was passed down from generation to generation, namely sea trade. It is important to note that the term "Chinese" and national affiliation that comes with this term was non-existent until the panChinese nationalism of 20th century. People primarily distinguished themselves by the dialects, regions they were born in and crafts that they performed. It is fair to say that orders from Beijing were regarded by the Hoklo as orders from outside.

The transition period between two dynasties - Ming and Qing was very dreadful for the Fujian province. In 1648, due to successive years of civil wars and starvation on the mainland, the number of Immigrants in Taiwan suddenly increased to 20,000. They were more eager to pay taxes and tributes to the Dutch East India Company that ruled over many parts of Taiwan at the time than stay on the mainland (Li, 2004: 50). Taiwan became the largest recipient of farmers seeking land and opportunities after Beijing lifted its coastal ban in 1684 . At the beginning of $18^{\text {th }}$ century many of the people who were registered in Zhangzhou and Quanzhou prefectures in Fujian province actually were living in Taiwan (Ng, 1993: 40). However the political situation was not the sole reason for the Hoklo people to leave Fujian for Taiwan. During the Ming and Qing Dynasties, natural disasters and epidemics such as floods, droughts, plagues, and typhoons were extremely common in southern Fujian. In the 185 years from 1631 to 1816 , there were eighty-four natural disasters, with one occurring in less than three years on average. Natural disasters were extremely dreadful and very diverse. Fujianese people experienced everything from heavy rains and five foot snow to enormous floods and epidemics that killed many. The continuous disasters led 
local farmers to complete bankruptcy. They had to leave their homes and migrate somewhere else to earn a living. Taiwan was a very good option at the time, especially regarding how close it is through the sea to Fujian.

Taiwan was a newly developed area during the Ming and Qing Dynasties, with a vast land, little population, fertile soil and suitable climate. Compared to the mainland, life in Taiwan was much more stable; living standards were higher, with plenty of opportunities for employment without fear of another political turmoil. Taiwanese soil was very rich for the vast variety of agricultural products like rice and sugar. Under a relatively small amount of government control, people had the chance to freely trade and grow rich, opportunity that was rare on the Mainland (Yang, 2001: 27). Eventually people got used to this kind of freedom and took it as granted. It became the part of the culture and something that was passed through generations.

Many Hakkas left mainland China for Taiwan during the same period as the Hoklo also due to the oppressive policies of the Qing government, such as the coastal ban. Even the story of where the Hakka came from in mainland China remains a mystery. But it is known for sure that the Hakka were often forced to change their place of residence, which is why, perhaps, they got their name客家, pronounced kejia in Mandarin and meaning "guest people". Since there were fewer of them on the island than the Hoklo people, they were forced to occupy lands in remote areas, especially in mountains. They moved into the hills to avoid collisions with the Hoklo. They were famous to be masters of mining, logging, camphor cultivation, and other mountain related crafts. However, there is genetic research that suggest that the Hakka and the Hoklo in Taiwan have identical DNA and both can be the descendants of Yue people (Lin, 2001: 102-112).

The distinction between "Mainlanders" and "Native Taiwanese" (referring to both the Hoklo and the Hakka), was a product of the rule of KMT. Right after Japan lost the Second World War in 1945 and Taiwan came under the rule of KMT, people from the mainland started to arrive. However, the largest amount of new immigrants was due to the KMT losing the civil war in 1949. The Chinese Nationalist Party was forced to retreat to Taiwan, bringing additional military personnel, people who worked for the government and their families. Most of these people were well educated. They already had this constructionist republican education and considered themselves Chinese. Initially, they expected that KMT would take over China once again and that they would be able to return to the mainland. Not considering permanent settlement in Taiwan, they identified themselves with the Chinese Nationalist Party, with their places of origin in China, and felt a strong sense of cultural superiority over the Taiwanese. More importantly, unlike the Taiwanese, they had relatives on the mainland. In addition, they were educated in accordance with the needs of the modern world, were citizens of a certain country, and trained from childhood to be loyal to the country of which they were citizens (Corcuff, 2002: 285).

It was believed that the indigenous peoples of Taiwan had lived on the island for thousands of years. There are sixteen officially recognized indigenous peoples, as well as a number of unrecognized smaller tribes. Interestingly, most of the indigenous people are Christians. People from different tribes began to gradually convert to Christianity after the KMT retreated to Taiwan in 1949. The traditional social organization of some of these tribes is mainly matriarchal with the wife responsible for the majority of family affairs. Many groups practiced genderbased division of labor: men hunting, while women did most of the cooking and farming. Traditional customs such as facial tattoos have been steadily getting less and less popular in recent decades, in part due to opposition from Christian churches (Minority Rights Group International, 2008).

In any case, in the conditions of the island state and constant emigration for many centuries, different ethnic groups were always in inter-ethnic marriages. During every period of immigration to Taiwan, immigrants themselves were predominantly males and the only way to get married is to find a wife within the local population. The first immigrants from Fujian were having babies with indigenous people; those who came after 1945 were marrying locals who already had lineage consisted of the Hoklo and indigenous blood. According to the research made by $\mathrm{Xu} \mathrm{Z}$. M. in 2002 the rate of inter-ethnic marriages after 1981 was as follows: Hoklo 15\%, 63.4\% in Hakka, $82 \%$ in Mainlanders, and $38.2 \%$ in aborigines (Xu, 2002: 13-16). According to the DNA tests, blood of Taiwanese people is full of genes from all those ethnic groups including aborigines, and now making it more and more difficult to categorize people this way anymore. Subsequently, this means that the phenotype of the Taiwanese population is formed according to the same environmental, economical and political circumstances specific for this island. Moreover this genetic phenotype formed due to interethnic marriages between certain ethnic groups is unique to the population of Taiwan (Lin, 2007: 5-16). As a result, logical conclusion will be that people who share this sort of unique mix of ethnicities will 
end up having some sort of different culture in terms of traditions and religion, which will make them different culturally from people with whom they had shared common ancestry with hundreds of years ago. Eventually, it's fair to say that these people will have their own sense of commonality which will lead to the necessity of self-governance, and the idea of having their own country will arise.

One of the functions of customs, especially in the form of folk religions, is the communication between the natural environment and human beings. This connection reflects the interaction between people and their environment, which is why premodern society is so diverse. After all, different people living in different environments develop different traditions. It is very difficult to talk about a clear distinction between religions in Taiwan, since all traditional religions like Confucianism, Taoism and Buddhism exist in parallel with each other. Gradually they begin to borrow some aspects from each other. Even though Confucianism, Taoism and Buddhism are all present in Taiwan, the folk beliefs, that in many ways combine practices from religions mentioned above and actually practised in temples that are registered as Buddhist or Taoist, are the most prominent and have the biggest influence on customs, habits and values of Taiwanese people. But there is a difference between folk religions and others. Most importantly folk religion is not formalized and it is not something that a person can be converted to by learning or by undergoing rituals. It is something that is passed on from generation to generation through customs and daily life activities and is constantly changing and transforming due to ethnic migration, natural environment, and political changes.

Originally, folk religions were famous to have enormous amount of Gods, but those that are the most significant for people of certain area are closely connected with the living experiences and environment that these people went through or lived in. When the first settlers from Fujian came to Taiwan, the first problems they faced were shipwrecks, plague, and the struggles with the aborigines. Due to all the dangers of sailing through Taiwanese strait people tend to ask for god's help. As a result, such gods as the goddess of the sea, Mazu, were worshipped by people the most. Even today Mazu is the most worshipped god in Taiwan. Originally in Southern Fujian, Mazu was the protector of fisherman, but in Taiwan her cult started to develop some local characteristics. There was a distinctive relationship between Mazu-worship and merchants who were sailing the sea and trading goods. Presumably these people, who played a dominant role in Taiwanese economic life throughout $18-19^{\text {th }}$, promoted her as the main Deity in Taiwan and also gave her new identity as the goddess of commerce. During the time Taiwan was under Japanese colonial rule Mazu eventually established herself in this role. Since the local Taiwanese people were prohibited to hold government positions, they sought careers in commerce. This also continued during early era of KMT rule before democratization. As a result, local people are now praying for Mazu in order to get some good fortune while doing business. The main commercial deity in Mainland China Kuan-ti failed to get a similar position in Taiwan. Instead, he was regarded by Taiwanese people mostly as a god of war due to the fact that temples built for praying to this god were mainly built by Qing soldiers and were used to maintain military spirit. Some customs were picked from Japanese Shintoism, like donation boxes at the front of the temple (Chen, 1995: 165-166).

Due to the fact that religion in Taiwan was not standardized, throughout history it continued to quietly develop and change under the influence of external factors, adapting to the needs of its population. Folk religions in Taiwan managed to avoid the fate of the Christianity in Europe, which, due to its regulation, has lost the flexibility to adapt and change. In Europe, a huge gap has formed between religious doctrine and the needs of the population. In Taiwan this is not the case, because religion exists in the same dimension as its believers. They live under the influence of same environmental factors therefore evolve together. Taiwanese society naturally chose the political system for itself that can adhere to the freedom of religious life. Unlike mainland China, where under Qing and then under Communist party, religious life is highly moderated and every new Buddhist cult is being proclaimed as “evil" (邪教 xiejiao) or backwarded (落後 luohou), the Taiwanese government, based on the experience of Japanese colonial government choose not to interfere and allow freedom of religion.

In nowadays China "Imagined community" in the meaning of modern nationalistic government exist as the supreme deity, an absolute monotheistic religion itself. The holy political trinity of this religion consists o patriotism, socialism (which in Chinese modern mythology means progress, because everything that is not socialistic is back-ward), and the rule of the Chinese Communist Party (Kuo, 2017: 14-16). All other religions must integrate this political holy trinity into their respective theologies. The population of China whose traditions and customs differ very much from province to province, are obliged to sacrifice their local culture in order to be part of one united China under one unified state religion and only minimum autonomy is allowed. 
In contrast, Taiwanese religious groups are likely to enjoy a lot of freedom. Temples also have huge influence on democratic elections as rallies and speeches made by politicians near temples are extremely important during elections. In other words, in Taiwan, state is the quest in the temple not the other way around.

Regulation by the state apparatus creates an obstacle for the natural development of any cultural phenomenon. Language is a prime example of this negative influence. To keep the huge country united, the Chinese government is obliged to impose a single language for the entire population. Now, almost the entire Chinese population is gradually switching to Mandarin and gradually forgetting their native dialects. It is worth noting that the so-called dialects of the Chinese language are rather separate languages than dialects, since they have different pronunciation and often, as in the case of Hoklo and Hakka, there are significant grammatical differences. Instead, the people of Taiwan are more respectful of their language history. Mandarin, based on the Peking dialect, which experienced strong Mongol influence, as well the Hoklo and Hakka languages, have preserved the legacy of the ancient Chinese languages while retaining more tones than modern Mandarin.

Language, like any organism, is constantly evolving, adapting and changing; when it is standardized, then it is driven into a framework from which it is very difficult to get out. The modern Hoklo and Hakka languages, although they come from southern Fujian, have absorbed many words from the languages of the aborigines of Taiwan. On the path of their development and adaptation to the new environment, they have evolved into a language that is less and less similar to the Fujian dialect. Even attempts of sinization of the Native Taiwanese by the KMT weren't successful. Almost entirely throughout the second half of the $20^{\text {th }}$ century, native "dialects" (方言 fangyan) of Hoklo and Hakka were regarded as vulgar. After democratization, it was obvious that dialects were still there and politicians, regardless of their political agenda, have to use native language during election campaigns (Shih, 2003: 89-102). Despite years of KMT rule, when native dialects were not appreciated, Taiwanese Hoklo was still the mostspoken language in Taiwan, and today about $70 \%$ of Taiwanese speak this language (Cheng, 1994: 362). Due to the fact that this language was not standardized and mostly was used as vernacular language, it continued to constantly evolve over the centuries and was influenced by other languages, like Japanese for example. As a result, this language, despite the fact that it came with the first immigrants from Southern Fujian, gradually evolved into something else and is already very different from the Southern Fujian dialect that still exist as vernacular language in the Fujian province of PRC. Furthermore, even Taiwanese Mandarin, which is the official language in Taiwan, is getting further from its Mainland counterpart. Because of the influence of Hoklo, Hakka languages and languages of the aborigine tribes there are one thousand, two hundred and eighty four characters, which is $18.3 \%$ of the seven thousand characters in the Modern Chinese List of Commonly Used Characters (現代漢語通用字表 xiandai hanyu tongyong zibiao) that have different pronunciations between Taiwan and Mainland. (Nan, 2008, pp. 65) Also, Taiwanese Mandarin, as well as Taiwanese Hoklo, use Traditional Chinese characters as a writing system, while Mainland Mandarin uses Simplified Characters.

As can be seen from the Taiwanese example, language does not stand still and is constantly evolving. The sense of commonality is closely connected with the language and it is constantly changing as well. In other words, with the change of language, the self-identification of the people is gradually changing. According to the study made by the Election Study Center of National Chengchi University in Taiwan, the amount of respondents who consider themselves as Chinese only is falling down almost every year. In 1992 almost 11\% of respondents considered themselves Chinese. In 2021, this number fell down to $2.7 \%$. As for the year 2021, the amount of respondents who consider themselves as Taiwanese only is $63.3 \%$; in 1992 it was $17.6 \%$. As for the year 2021, the amount of respondents who consider themselves as Taiwanese and Chinese is $31.4 \%$; this number is also falling down - in 1992 $46.4 \%$ people identified themselves as both Chinese and Taiwanese. Also, it should be mentioned that in 1992, Taiwanese people still had memories of living under authoritarian KMT rule and they probably were afraid to identify themselves as Taiwanese only (Election Study Center, 2021).

Most pro-democracy movements in Taiwan since the 1980s emphasized the necessity of preserving local culture and history. The idea of "nation" meant to be conceptualized on the basis of the land inhabited by the people of Taiwan and governed by the national government of Taiwan, rather than on the basis of an imaginary concept of united China promoted by the KMT. During the years of authoritarian KMT rule, Taiwan had the same problem as The Soviet Union and Modern day China, where the ruling party has almost absolute control over natural resources of the Country. The rights to use and extract resources are delegated to government lobbyists and they 
pump out all possible resources from the earth, guided by the goal of reaching certain heights of GDP, rather than worrying about the preservation of the environment. For such environmentalist prodemocracy movements, such as the Southern Green Revolution, which was active in second largest city of Taiwan, Kaohsiung democracy and protection of the environment of the motherland go hand in hand. As one of activists put it while advocating establishment of new park: "Given that Camp Wei-wu used to be a marsh, we should also recreate a wetland environment, so that the park can, once again, attract fireflies, geese, ducks, and Pheasant-tailed Jacanas that are indigenous to Taiwan.... Only by restoring the park to its original state, can we rebuild an ecosystem with a rich diversity that is truly Taiwanese and can we call this a worthy project" (Lee, 2007: 114-138).

Man is part of nature, they are one, and are the part of one system. A person is tied to the land on which he grew up and his connection with this land is a catalyst for the development of culture and unique identity on this territory. On the island of Taiwan after democratization, residents are free to move around the mountains and rivers, even if the cliffs are too steep and dangerous. In China, many places, such as rivers and mountains, that for centuries where part of identity of people, where transformed for commercial or industrial use. Many mountains have turned into sightseeing where people can enter only through the gate that is guarded. People are allowed to visit only certain paths from which they are not allowed to turn off. Some rivers were completely cut off from the population and exist only for industrial use. Some mountains have even been flattened, and the population that lived there getting have been moved somewhere else (Zhang, 2004: 517-527). The modern day Chinese citizen, especially in the Northern China, is completely cut from the nature that his ancestors were together with. This is of great significance because the Chinese population is gradually losing their connection with their land and their uniqueness. Their identity is completely determined by their patriotic schooling and government narratives, which is usually promoting Marxism and Cult of the State over traditional Chinese customs, especially regarding the fact that all information from outside the government censorship is prohibited. Chinese society has become extremely constructionist and the establishment of "imagined community" under communist banner is inevitable.

The state that exists to achieve certain industrial goals died in Taiwan with the birth of democratization. Considering the diversity of the ethnic composition of Taiwan and especially the presence of indigenous Aborigines, the ecological factor is incredibly important for building a national idea. $60 \%$ of Taiwan's forest ecosystems are still home for traditional settlements, hunting grounds, and gathering areas of Taiwan's aborigines (Chuang, 2006: 138). No matter how strong the individual's attachment to the land, the Taiwanese example shows that it is not transcendental and there is unlikely to be any sacred unbreakable meaning behind this connection. A person's ancestors, who were born two generations earlier on another land, do not define his identity at this particular moment, since he himself lives on another land in different environment. In other words, attachment to one's land is constantly changing from generation to generation. During the reign of the KMT, Taiwanese students received education primarily about China and only then about Taiwan. After democratization this practice was fiercely criticized by the population. As stated by a newspaper note written by a Taiwanese writer named Wu Chin-fa in 1993 about necessity to educate people about their own land that they live in right now: "So often we talk to our kids about the love to our native land. After a while, the talk simply becomes a sham, since we never teach them anything about the place they actually live. I am not opposed to teaching Yellow River, Yangtze River, in school. But before teaching our children Yellow River or Yangtze River, shouldn't we tell them about our own Takao Hill and Ai River? They shouldn't be just feeling happy from visiting the monkeys. There is so much more that we could teach them. There is this rich history and culture that they should know" (Wu, 1993: 32-43).

Conclusion. The Taiwanese example shows that ethnic identities as a sense of commonality that bring certain groups of people together is not permanent, but it does indeed change very slowly. When a population moves to another land, after one or more generations it will develop some other new identity. Being in a new environment, old customs, economic activity and religions will transform and adapt, which will also lead to changes in language. Gods, which were worshipped by ancestors earlier will acquire new meanings based on the needs of believers in the new environment. Old ethnic demarcation will lose its original meaning due to hundreds of years of intermarriages. The emergence of a new, modern state is possible only if there is already some sense of solidarity within the population. In order to impose the population into one nation by means of "printed capitalism", a certain initial condition must be present. This condition is sense of commonality. It is determined by the environment in which the population is located over a long period of time. In a totalitarian state of enormous size, people are obliged to sacrifice 
their local culture, religion and language to maintain one unity. Since there are huge differences between many of these populations, suppression of local culture and standardization of everything, from economic activity to language, is a necessity and has been practised in China since the times of Qin Shi Huang.

People immigrated to the island of Taiwan many centuries ago because in the old country their way of life and freedoms were constantly neglected for the sake of the political goals of the central government. People in Taiwan are not only reluctant to sacrifice their culture for the idea of one country, they also want to preserve what they always had - freedom to do what they want. Since the first immigrants from Fujian, it was the land of those who are fed up with someone ruling them from elsewhere. The idea of having their own government appears naturally, because people who live on this land know better how to govern themselves. Freedom of religion, freedom of movement and freedom of economic activity are the main prerequisites for the emergence of a modern nation in Taiwan, since only the democratic selfgovernance will be able to preserve their traditional way of existence.

\section{BIBLIOGRAPHY}

1. Anderson B. R. O. (1991). Imagined communities: Reflections on the origin and spread of nationalism (Rev. and extended ed.). Verso. P. 6-7.

2. Baiping Z., Shenguo M., Ya T., Fei X., Hongzhi W. Urbanization and De-Urbanization in Mountain Regions of China. Mountain Research and Development. 2004. № 24(3). P. 206-209. URL: http://www.jstor.org/stable/3674554.

3. Carson, Mike T. (2016). Archaeological Landscape Evolution: The Mariana Islands in the Asia-Pacific Region. Springer (published June 18, 2016). P. 23.

4. Chen, Hsin-chih (1995). The Development of Taiwanese Folk Religion, 1683-1945. Ph.D. dissertation, Department of Sociology, University of Washington. 137-138, P. 165-166.

5. Cheng, Robert L. (1994). Chapter 13: Language Unification in Taiwan: Present and Future. In Rubinstein, Murray (ed.). The Other Taiwan: 1945 to the Present. M.E. Sharpe. P. 362.

6. Corcuff S. (2002). Memories of the Future: National Identity Issues and the Search for a New Taiwan: National Identity Issues and the Search for a New Taiwan (1st ed.). Routledge. P. 285.

7. Election Study Center (2021), National Chengchi University. URL: https://esc.nccu.edu.tw/PageDoc/ Detail?fid $=7800 \& i d=6961$ [accessed 13 October 2021]

8. Kuo C. (2017). Introduction: Religion, State, and Religious Nationalism in Chinese Societies. In C. Kuo (Ed.), Religion and Nationalism in Chinese Societies (pp. 13-52). Amsterdam University Press. URL: https://doi.org/10.2307/j.ctt1zkjzkd.5.

9. Lee, Anru. (2007). Southern Green Revolution: Urban Environmental Activism in Kaohsiung, Taiwan. City \& Society, 19 (1), 114-138

10. Minority Rights Group International, World Directory of Minorities and Indigenous Peoples - Taiwan : Indigenous peoples, 2008. URL: https://www.refworld.org/docid/49749c9fc.html [accessed 13 October 2021].

11. Ng, James. (1993). Windows on a Chinese past. 4 vols. Dunedin: Otago Heritage Books. Ngai, Mae M. 2004 , p. 40.

12. Shi Zhihong. (1995). China's overseas trade policy and its historical results: $1522-1840$. Intra-Asian trade and the world market. Routledge. P. 4-23.

13. Shih C.-F. Language and ethnic politics in taiwan. International Journal of Peace Studies. 2003. № 8 (2). P. 89 -102. URL: http://www.jstor.org/stable/41852903.

14. Wu Chin-fa (1993). Understanding Ch'ai-shan from Humanistic Perspectives. In Ch'ai-shan-ism. T'u Hsing-chi, ed. P. 32-43. Taichung: Ch'enhsing.

15. Wu C.-Y. (2021), Hoklo speakers and Taiwanese identity in south Taiwan. Asian Politics \& Policy, p. 150-164.

16. Xu Z. M. (2002). Taiwan and Fujian 3 generation intermarriage survey analysis. Newsletter of the Chinese Statistical Association. 13 (11), p. 13-16.

17. 南基弘，兩岸語音規範標準之差異探析一以《現代漢語通用字表》為範疇（碩士論文），56。

18. 张兴华; 郑连斌; 宇克莉; 胡莹; 程智; 王杨; 薛虹; 邓维; 时芯, 闽南人的体质特征，人类学学报，2015, 34 (04) : 516-527。

19. 李祖基，大陆移民渡台的原因与类型，台湾研究集刊，2004（3）：50。

20. 杨彦杰，《“林日茂”家族及其文化》，载《台湾研究集刊》2001 年第 4 期 27 页。

21。林瑤棋，臺灣閩客族群的血緣與修譜新觀念，臺灣源流（2007），（38），5-16。

22. 林瑤棋，閩客都是越族人，自由時報（2001 年 5 月 5 日），第 15 版

23. 莊慶信，臺灣原住民的生態智慧與環境正義－－環境哲學的省思，哲學與文化，30，頁 138。

\section{REFERENCES}

1. Anderson, B. R. O. (1991). Imagined communities: Reflections on the origin and spread of nationalism (Rev. and extended ed.). Verso. pp. 6-7.

2. Baiping, Z., Shenguo, M., Ya, T., Fei, X., \& Hongzhi, W. (2004). Urbanization and De-Urbanization in Mountain Regions of China. Mountain Research and Development, 24(3), 206-209. http://www.jstor.org/stable/3674554.

3. Carson, Mike T. (2016). Archaeological Landscape Evolution: The Mariana Islands in the Asia-Pacific Region. Springer (published June 18, 2016). p. 23.

4. Chen, Hsin-chih (1995). The Development of Taiwanese Folk Religion, 1683-1945. Ph.D. dissertation, Department of Sociology, University of Washington. 137-138, p. 165-166. 
5. Cheng, Robert L. (1994). Chapter 13: Language Unification in Taiwan: Present and Future. In Rubinstein, Murray (ed.). The Other Taiwan: 1945 to the Present. M.E. Sharpe. p. 362.

6. Chuang, John B. (2006). Taiwan yuan zhumin de shengtai zhihui yu huanjing zhengyi - huanjing zhexue de xing si [The Ecological Wisdom and Environmental Justice of the Aborigines of Taiwan-Reflections on Environmental Philosophy]. Taibei: zhexue yu wenhua yuekan zazhi she. p. 138. [in Chinese].

7. Corcuff, S. (2002). Memories of the Future: National Identity Issues and the Search for a New Taiwan: National Identity Issues and the Search for a New Taiwan (1st ed.). Routledge. p. 285.

8. ElectionStudyCenter(2021),NationalChengchiUniversityhttps://esc.nccu.edu.tw/PageDoc/Detail?fid=7800\&id=6961 [accessed 13 October 2021].

9. Kuo, C. (2017). Introduction: Religion, State, and Religious Nationalism in Chinese Societies. In C. Kuo (Ed.), Religion and Nationalism in Chinese Societies (pp. 13-52). Amsterdam University Press. https://doi.org/10.2307/j.ctt1zkjzkd.5.

10. Lee, Anru. (2007). Southern Green Revolution: Urban Environmental Activism in Kaohsiung, Taiwan. City \& Society, 19(1), 114-138.

11. Li Zuji. (2004). Dalu yimin du tai de yuanyin yu leixing [Reasons and Types of Mainland Immigrants Crossing Taiwan]. Taiwan: Taiwan research quarterly. (3): p. 50. [in Chinese].

12. Lin Yaoqi. (2001). Min ke dou shi yue zuren [All Hoklo and Hakka are Yuenan people]. Taiwan: ziyou shibao. (15): p. 102-112 [in Chinese].

13. Lin Yaoqi. (2007). Taiwan min ke zuqun de xieyuan yu xiu pu xin guannian [The Blood Relationship and New Ideas of Genealogy Compilation of Fujianese Hakka in Taiwan]. Taiwan: taiwan yuanliu. p. 5-16 [in Chinese].

14. Minority Rights Group International, World Directory of Minorities and Indigenous Peoples - Taiwan : Indigenous peoples, 2008, available at: https://www.refworld.org/docid/49749c9fc.html [accessed 13 October 2021].

15. Nan, Jihong. (2008). Biaozhun liang'an yuyin guifan fenxi - yi "xiandai hanyu tongyong zi biao" wei guangfan tan [A Study of the Distinction of Pronunciation Standards between Taiwan and Mainland China]. National Taiwan Normal University. p. 65 [in Chinese].

16. Ng, James. (1993). Windows on a Chinese past. 4 vols. Dunedin: Otago Heritage Books. Ngai, Mae M. 2004 , p. 40.

17. Shi Zhihong. (1995). China's overseas trade policy and its historical results: $1522-1840$. Intra-Asian trade and the world market. Routledge. p. 4-23.

18. Shih, C.-F. (2003). Language and ethnic politics in taiwan. International Journal of Peace Studies, 8(2), 89-102. http://www.jstor.org/stable/41852903.

19. Wu Chin-fa (1993). Understanding Ch'ai-shan from Humanistic Perspectives. In Ch'ai-shan-ism. T'u Hsing-chi, ed. pp. 32-43. Taichung: Ch`enhsing.

20. Wu, C.-Y. (2021), Hoklo speakers and Taiwanese identity in south Taiwan. Asian Politics \& Policy, p. 150-164.

21. Xu Z. M. (2002). Taiwan and Fujian 3 generation intermarriage survey analysis. Newsletter of the Chinese Statistical Association. 13(11), p. 13-16.

22. Yang Yanjie. (2001). "Linrimao" jiazu ji qi wenhua ["Lin Rimao" Family and Its Culture]. Taiwan: Taiwan research quarterly. (04): p. 27 [in Chinese].

23. ZHANG Xinghua, ZHENG Lianbin,YU Keli, HU Ying, CHENG Zhi, WANG Yang, XUE Hong, DENG Wei, SHI Rui. (2015). Minnan ren de tizhi tezheng [A Study of the Physical Characteristics of the Minnan Han]. Tianjin Normal University, College of Life Sciences, Acta Anthropologica Sinica. (04): p. 517-527. [in Chinese]. 